\title{
Regulation of thyroid hormone-induced development in vivo by thyroid hormone transporters and cytosolic binding proteins
}

\author{
Jinyoung Choi, Christine L. Moskalik, Allison Ng, Stephen F. Matter, Daniel R. Buchholz
}

Department of Biological Sciences, University of Cincinnati, Cincinnati, OH 45221-0006, USA

\begin{abstract}
Differential tissue sensitivity/responsivity to hormones can explain developmental asynchrony among hormonedependent events despite equivalent exposure of each tissue to circulating hormone levels. A dramatic vertebrate example is during frog metamorphosis, where transformation of the hind limb, brain, intestine, liver, and tail are completely dependent on thyroid hormone (TH) but occurs asynchronously during development. TH transporters (THTs) and cytosolic TH binding proteins (CTHBPs) have been proposed to affect the timing of tissue transformation based on expression profiles and in vitro studies, but they have not been previously tested in vivo. We used a combination of expression pattern, relative expression level, and in vivo functional analysis to evaluate the potential for THTs (LAT1, OATP1c1, and MCT8) and CTHBPs (PKM2, CRYM, and ALDH1) to control the timing of THdependent development. Quantitative PCR analysis revealed complex expression profiles of THTs and CTHBPs with respect to developmental stage, tissue, and TH receptor $\beta(\mathrm{TR} \beta)$ expression. For some tissues, the timing of tissue transformation was associated with a peak in the expression of some THTs or CTHBPs. An in vivo overexpression assay by tail muscle injection showed LAT1, PKM2, and CRYM increased TH-dependent tail muscle cell disappearance. Co-overexpression of MCT8 and CRYM had a synergistic effect on cell disappearance. Our data show that each tissue examined has a unique developmental expression profile of THTs and CTHBPs and provide direct in vivo evidence that the ones tested are capable of affecting the timing of developmental responses to TH.
\end{abstract}

\section{Introduction}

At some point during post-embryonic development in all vertebrates, a peak in blood levels of thyroid hormone (TH) occurs and induces critical TH-dependent developmental events (Buchholz et al., 2006). TH regulates developmental events by binding with TH receptors (TRs) in the cell nucleus and changing gene expression, leading to extensive morphological and/or functional changes in TH-target tissues (Shi, 1999). Importantly, even though organs and tissues are exposed to the same circulating levels of TH, TH-dependent events occur at different time points during development, that is, in a tissue asynchronous manner (Brown et al., 2005; Furlow and Neff, 2006). A dramatic example of TH-dependent tissue asynchrony is frog metamorphosis, where TH induces (1) hind limb elongation at the start of metamorphosis when TH levels are low, (2) tail resorption during metamorphic climax when TH levels peak, and (3) TH-dependent remodeling of the other organs when TH levels are intermediate.

Tissue asynchrony is due to a combination of (1) differential sensitivity to TH, i.e., tissues differ in the blood concentration of TH required to initiate TH-dependent gene expression and tissue transformation and (2) differential responsivity to TH, i.e., tissues differ in rate of TH-dependent tissue transformation (Shi et al., 1996). Above a threshold TH concentration in the blood, a tissue becomes sensitive to transform, and the response to TH (rate of transformation) is proportional to the amount of $\mathrm{TH}$ signaling and constrained by the inherent tissue-specific rate of developmental change. Sensitivity and responsivity are related, because both depend on mechanisms that regulate TH entry into the cell from circulation, transport across the plasma membrane, transit through the cytoplasm, and binding of TRs in the cell nucleus to regulate gene expression (Buchholz et al., 2011). At least four candidate mechanisms are known or hypothesized to affect tissue sensitivity/responsivity, based on expression and activity levels of (1) TR and 
associated transcription co-factors, (2) TH metabolizing enzymes (deiodinases), (3) TH transport from the blood across the plasma membrane, and (4) cytosolic TH binding proteins (Shi et al., 1996). Previous in vivo functional analyses on deiodinase type 3 (Huang et al., 1999), TRs (Buchholz et al., 2004; Choi et al., 2015; Hollar et al., 2011; Nakajima et al., 2012), and various transcription factors (Matsuda et al., 2009; Paul et al., 2007; Sato et al., 2007) using overexpression by transgenesis or tail muscle cell injection showed changes in timing of tissue development, i.e., affected tissue sensitivity and responsivity to TH (Hollar et al., 2011). However, the role of TH transporters (THTs) and cytosolic $\mathrm{TH}$ binding proteins (CTHBPs) that may also impact $\mathrm{TH}$ signaling has not been experimentally examined in vivo.

Many THTs have been identified, including monocarboxylate transporters (MCT8, MCT10), L-type amino acid transporters (LAT1, LAT2), and organic anion transporting proteins (OATP1c1, OATP1A2 and OATP4A1) (Friesema et al., 2008, 2003; Hennemann, 2001; Pizzagalli et al., 2002). Different THTs have different transport efficiencies and specificities for TH, where MCT8, MCT10, and OATP1c1 have the highest affinity and specificity for TH transport, and LAT1 and 2 serve to transport subsets of amino acids as well as iodothyronines (Heuer and Visser, 2009). In-vitro studies have shown that LAT1 enhances TR-mediated gene transcription in a Xenopus oocyte transcription assay (Ritchie et al., 2003; Shi et al., 2002). In addition, LAT1 is strongly up-regulated during TH-dependent development, suggesting that it may play an important in vivo role in TH signaling (Liang et al., 1997). The strongest evidence for an in vivo role of TH transport comes from the association of mutations in MCT8 with severe X-linked mental retardation and elevated circulating levels of T3, the active form of TH (Jansen et al., 2008). Most TH transporters are expressed in varying patterns in different types of tissues in mammals (Heuer and Visser, 2009) and frogs (Connors et al., 2010). However, there has been no direct evidence that THTs play a role in control of developmental asynchrony.

Cytosolic TH binding proteins (CTHBPs) were first identified as distinct from serum TH binding proteins (Tata, 1958) and are now well-established in mammals and amphibians (Yamauchi and Tata, 2001). The CTHBPs identified to date do not represent a specific protein family but rather are diverse, multifunctional proteins (Yamauchi and Tata, 2001). In frogs, two CTHBPs have been identified: aldehyde dehydrogenase 1 (ALDH1) and pyruvate kinase subtype M2 (PKM2) (Shi et al., 1994; Yamauchi and Tata, 2001). Two other CTHBPs in frogs have been detected but not identified (Yamauchi and Tata, 1997; Yoshizato and Frieden, 1975). ALDH1 catalyzes aldehyde oxidation and synthesis of retinoic acid and was independently identified as a cytosolic TH binding protein (Yamauchi and Tata, 1994). TH interacts with ALDH1 as a non-competitive inhibitor of dehydrogenase activity (Yamauchi and Nakajima, 2002). PKM2, a central player in cellular energy metabolism, was identified as a CTHBP by protein purification of TH binding activity (Kitagawa et al., 1987). PKM2 exists in the cytoplasm as a tetramer (high enzymatic activity) or monomer (low enzymatic activity), depending on posttranslational modifications and allosteric regulators. The presence of fructose 1,6-bisphosphate and serine favors the tetrameric form and allosterically activates PKM2, whereas phenylalanine and T3 favor the monomer and allosterically inhibit PKM2 (Christofk et al., 2008; Gui et al., 2013; Morgan et al., 2013; Williams et al., 2006). Though not studied previously in amphibians, CRYM was discovered first as a CTHBP and was much later found to have NADH/NADPH-dependent ketimine reductase activity, involved in lysine catabolism, and T3 strongly and non-competitively inhibits this enzyme activity (Hallen et al., 2011). CRYM mutations are associated with deafness in humans, with a link to TH signaling (Oshima et al., 2006). In mouse, CRYM knockout affected serum and tissue T3 turnover but not peripheral T3 action in vivo, and there was no effect on mouse hearing (Suzuki et al., 2007).

The mechanisms of CTHBP action in TH signaling are not known, but CTHBPs may shuttle TH to the nucleus to facilitate TH signaling or sequester TH in the cytoplasm and reduce TH signaling (Shi et al., 1996). Indeed, CRYM can increase cytoplasmic T3 retention and can suppress T3-induced gene expression in cell culture (Mori et al., 2002). Similarly, PKM2 or CRYM expression is negatively correlated with induction of TH response genes (Ashizawa and Cheng, 1992; Mori et al., 2002; Shi et al., 1994). On the other hand, TH-induced gene regulation was not affected by MCT8 alone but was increased in combination with CRYM (Van Mullem et al., 2011). Also, a positive correlation exists between cytosolic T3-binding activity from unidentified proteins and metamorphic changes in hind limb, intestine, head, and liver, but not in tail (Yamauchi and Tata, 1997). Equilibrium dissociation constants (Kd) among known CTHBPs for TH range from $0.1 \mathrm{nM}$ to over $100 \mathrm{nM}$, indicating that some CTHBPs may be of only pharmacological importance and not relevant at physiological TH levels (Yamauchi and Tata, 2001). Also, the ability 
of T3 to inactivate enzyme activity of CTHBPs suggests that a potential role of an interaction between CTHBPs and TH may be to modulate enzyme activity in addition to modulate intracellular TH bioavailability for transcription regulation.

Here, we address the role of THTs and CTHBPs in tissue-specific regulation in TH-dependent development in frog metamorphosis using expression and functional analyses. We quantified expression profiles of three THTs (LAT1, MCT8 and OATP1c1) and three CTHBPs (PKM2, ALDH1 and CRYM) in five TH-target tissues/organs (hind limb, liver, intestine, brain, and tail) at seven developmental stages throughout the larval period including metamorphosis. Also, we overexpressed THTs (LAT1 and MCT8) and CTHBPs (PKM2 and CRYM) in tail muscle cells to determine the effect on the rate of TH-dependent muscle cell disappearance.

\section{Materials and methods}

\subsection{Animal care and rearing}

Breeding was induced by injecting human chorionic gonadotropin (Sigma Aldrich, St. Louis, MO) into Xenopus tropicalis (20 U in the evening followed by a $200 \mathrm{U}$ booster in the morning for both sexes) and into Xenopus laevis (600 U in females and $100 \mathrm{U}$ in males in the evening). Tadpoles were reared and staged according to Nieuwkoop and Faber (NF) (Nieuwkoop and Faber, 1994) until tissue harvest and/or tail injection. Tadpoles were reared at $25^{\circ} \mathrm{C}$ and $19{ }^{\circ} \mathrm{C}$ for X. tropicalis and X. laevis, respectively, and fed powered food (Sera Micron) with daily water changes. The use of animals in this study was approved by the University of Cincinnati Institutional Animal Care and Use Committee (IACUC protocol \# 06-10-03-01).

\subsection{RNA isolation, cDNA synthesis, and quantitative PCR}

Hind limb, brain, liver, intestine, and tail from staged tadpoles anesthetized in benzocaine (Sigma) were isolated, snap frozen on dry ice, and then stored at $-80^{\circ} \mathrm{C}$ until RNA isolation. The intestine was flushed of its contents using a 30-gauge needle filled with phosphate buffered saline at $60 \%$ mammalian strength prior to freezing. Three to six replicates were obtained, but for smaller organs, each replicate was pooled from 2 to 3 individuals. Total RNA was isolated using TRIzol (Invitrogen) according to manufacturer's instructions. Two $\mu \mathrm{g}$ of RNA were used to synthesize cDNA, following the manufacturer's protocol (Multiscribe reverse transcriptase kit, Applied Biosystems). Quantitative PCR (qPCR) was carried out with 1-2 $\mu \mathrm{L}$ cDNA in $20 \mu \mathrm{L}$ reactions using FAM-labeled primer/probe sets (Table 1) and Universal Master Mix (Applied Biosystems) on a 7300 Real Time PCR System with default reaction conditions $\left(50{ }^{\circ} \mathrm{C} 2 \mathrm{~min}, 95{ }^{\circ} \mathrm{C} 10 \mathrm{~min}\right.$, then 40 cycles of $95{ }^{\circ} \mathrm{C}$ $10 \mathrm{~s}, 60^{\circ} \mathrm{C} 1 \mathrm{~min}$ ) (Applied Biosystems). qPCR standards (1:3 serial dilutions) were made from NF stage 62 whole body tadpole mRNA and used to quantify relative expression levels among stages and tissues. qPCR runs where slopes of the standard curves (generated using serial dilutions of cDNA from NF62 whole bodies) were outside the range of -3.40 to -3.90 (a slope of -3.54 reflects $100 \%$ amplification efficiency) and $R^{2}$ values were less than 0.990 were not included in the analyses. A control sample (1/30 dilution of cDNA from NF62 whole bodies) was included in each qPCR run and used to evaluate the consistency among runs. Non-template controls were used in each qPCR run and failed to detect reaction product contamination. Each replicate was run in duplicate in qPCR, and the values were averaged for expression analysis.

Table 1. Quantitative PCR primers and probes for TR $\beta$, THTs and CTHBPs.

\section{Gene}

Forward primer $\left(5^{\prime}-3^{\prime}\right)$

rpL8

AGAAGGTCATCTCATCTGCAAACAG

LAT1

GTTCGCTACCTACCTGCTCAAG

MCT8

ACCGAGGAACAGGGTATGGA

OATP1c1 GGCATTTACACACTGGTCATACG
Reverse primer $\left(5^{\prime}-3{ }^{\prime}\right)$

FAM-labeled probe $\left(5^{\prime}-3^{\prime}\right)$ Product (bp)

CTGCCATGTGAAGACC

98

CAACCCCAACAATAGCT

80

CAGTCAGCAGCAAGATA

133

CCTGGTAGCTGCTTTCACACT

83

ACAACTGGAGAGCAGAAAAAGATCA CCAACCCAAGCTGTCTTG

ATCCCCGCAAGAACC 
Gene

Forward primer $\left(5^{\prime}-3{ }^{\prime}\right)$

PKM2 GGGAGACTGCAAAGGGAGACTA

CRYM CGGCAGTTTCAGCAATAGCAA

ALDH1 GCCTGTTGGAGTAT
Reverse primer $\left(5^{\prime}-3^{\prime}\right)$

GGTGGAAAATGGCTGCTTCTG

GATCCCAGAATGCACAAGATTTCAG

GGAGCAATTTTCCA
FAM-labeled probe $\left(5^{\prime}-3^{\prime}\right)$ Product (bp)

ATGCAGCATGCTATTGC $\quad 87$

CAAAGCTCCTTAAGCCC $\quad 70$

AATCCCATGGAACTTTC $\quad 72$

\subsection{Cloning of plasmid constructs for tail injections}

LAT1, MCT8, PKM2, and CRYM were PCR amplified (primers in Table 2) from a X. tropicalis cDNA library made for gene expression analysis above or from pBluescript SK(-)_LAT1 (IU12) and_PKM2 (gifts from Dr. Y.-B. Shi) and cloned into the SacII site of pHGCR-lox to replace DsRed2. The pHGCR-lox plasmid (sequence is available on request) was made by standard cloning techniques and gene synthesis (DNA2.0). To make pHGC-CRYM-C-MCT8-lox, we designed an oligo linker (5' GGCCGCGCGC 3 ') and ligated it into the NotI site of pHGC-MCT8-lox to generate one more BssHII site, from which the C-MCT8 fragment was subcloned into pHGC-CRYM-lox to make pHGCCRYM-C-MCT8-lox. Plasmid DNA was purified using Plasmid Maxi prep kit (Qiagen) and precipitated with sodium acetate and ethanol.

Table 2. Primers for subcloning THTs and CTHBPs into expression plasmids for tadpole tail muscle injections.

\begin{tabular}{|c|c|c|c|}
\hline $\begin{array}{c}\text { Gene } \\
\text { (species) }\end{array}$ & Forward primer $\left(5{ }^{\prime}-3{ }^{\prime}\right)$ & Reverse primer $\left(5^{\prime}-3^{\prime}\right)$ & $\begin{array}{l}\text { Product } \\
\text { (bp) }\end{array}$ \\
\hline $\begin{array}{l}\text { LAT1 }(X \\
\text { tropicalis })\end{array}$ & CATCATCCGCGGGCCACCATGGCCGCAGACAGCGTG & CATCATCCGCGGTTAGGACTCCTGGGGGACAGCC & 1524 \\
\hline $\begin{array}{l}\text { MCT8 }(X \\
\text { tropicalis })\end{array}$ & CATCATCCGCGGGCCACCATGGAAGAAGAAGCAGAAGAGGACGAG & CATCATCCGCGGCTACACACATTCATCTGTTACTGGGCTCCC & 1500 \\
\hline $\begin{array}{l}\text { PKM2 }(X \\
\text { tropicalis })\end{array}$ & CATCATCCGCGGGCCACCATGTCTGAGGCAGGTAGTGCTTTCATTC & CATCATCCGCGGTTAAGGCACTGGAACAACACGCATTG & 1584 \\
\hline $\begin{array}{l}\text { CRYM } \\
(X . \\
\text { tropicalis })\end{array}$ & CATCATGCGCGCGTCGACACCGGTCCGCGGGCCACCATGGGCGAGCAGCCGGCTTT & CATCATGCGCGCCCGCGGTCATTTATTTTCAGCCAGCCAGGA & 934 \\
\hline $\begin{array}{l}\text { ALDH1 } \\
\text { (X. laevis) }\end{array}$ & CATCATACCGGTATGTCAGAGAAAACCATTCTACATGGTTTGCC & CATCATAGATCTTTAGGAATTCTTCTGAGAAATTTTCATGATA & 1520 \\
\hline
\end{tabular}

\subsection{Tail muscle injections}

Tadpoles of $X$. laevis reared in stock tanks until NF stage $54-56$ were pre-heat shocked at $32{ }^{\circ} \mathrm{C}$ for $5 \mathrm{~min}$. The next day, tadpoles were briefly anesthetized in benzocaine and injected with the control plasmid pHGCR on the left side and a THT or a CTHBP expression plasmid (see Fig. 3A) on the right side of the tail, as described previously (Hollar et al., 2011). Briefly, $0.5 \mu \mathrm{L}$ of DNA ( $2 \mu \mathrm{g} / \mu \mathrm{L}$ ), containing $0.05 \% \mathrm{w} / \mathrm{v}$ fast green dye (Sigma), was injected into two myomeres on each side of the tail. Tadpoles were given daily heat shocks at $33-34{ }^{\circ} \mathrm{C}$ for an hour to induce gene expression beginning the day of injection. Treatment with $2 \mathrm{nM} \mathrm{T3}$ started on the day after tail injection. $2 \mathrm{nM}$ T3 is near the sensitivity threshold for the tail and was chosen to increase the ability of the assay to detect effects of overexpressed genes that increased the effect of T3. The experiments using LAT1 and MCT8 were conducted 2-3 times with comparable results, and thus the experiments with PKM2, CRYM, CRYM + MCT8 were each conducted once. The number of tadpoles injected, the number of cells per tadpole, and the total number of cells per hormone treatment per gene are enumerated in Suppl. Table 1. Cell fluorescence appeared to reach a maximum intensity and maximum cell number five days after plasmid injection, thus from day 5 to 14, GFP-positive cells in the tail muscle were imaged daily using a fluorescent microscope and counted manually to determine the rate of cell disappearance. The disappearance of any one cell was not gradual but occurred within $24 \mathrm{~h}$. Water and hormone were changed daily.

To confirm THT and CTHBP mRNA expression from injected plasmids, each plasmid (i.e., control, LAT1, MCT8, PKM2, CRYM, and MCT8 + CRYM) was injected into multiple sites on a NF56-57 tadpole tail followed by daily heat-shock to induce GFP expression. Tail tissues in the region of injection were then harvested on the fifth day after injection to isolate RNA, synthesize cDNA, and measure LAT1, 
MCT8, PKM2, CRYM, and the reference gene rpL8 by qPCR. Two to three tadpoles were used for each plasmid. To analyze data, the ddCt method was used (Livak and Schmittgen, 2001).

\subsection{Statistical analysis}

Gene expression data were tested for normality and heteroskedasticity and conformed to assumptions of analysis of variance (ANOVA) (JMP Statistical software). ANOVA was performed to determine if there were significant differences among stages of development (Table 3). The threshold $P$-value of significance was set at 0.05 . For any tissue and gene that yielded a $P$-value of 0.05 or less, a post hoc, pair-wise comparison was performed using the Tukey-Kramer method. To test for a significant effect of THT and CTHBP on cell disappearance, a generalized linear mixed model (GLMM) was used (Bates et al., 2012; Marschner, 2012; The R Core Team, 2013). In our data, there are $n$ trials in each tail (i.e., total number of GFP positive muscle cells), and $x$ number of "successes" (i.e., cells disappearing). Our response variable is the percent of muscle cells surviving, as calculated by $y=100 * x / n$. Thus, GLMM analysis is appropriate and ANOVA is not (Warton and Hui, 2011). In the model, injected gene, TH treatment, and their interaction were fixed effects, and individual tadpoles and time (treatment days) were random effects. We evaluated which effects affected the rate of disappearance of fluorescent cells in tadpole tail muscle.

Table 3. Statistical analysis of THT and CTHBP expression levels in different tissues across developmental stages.

\begin{tabular}{|c|c|c|c|c|c|c|}
\hline Gene & Statistics & Brain & Hind limb & Intestine & Liver & Tail \\
\hline \multirow{2}{*}{ LAT1 } & $F$ & 0.9199 & 5.5079 & 5.237 & 1.869 & 2.0587 \\
\hline & $n$ & $3-5$ & $3-5$ & $4-6$ & $5-6$ & $4-6$ \\
\hline \multirow{2}{*}{ OATP1c1 } & $F$ & 6.9451 & 6.8307 & 3.9326 & 4.4839 & 3.4851 \\
\hline & $n$ & $3-5$ & $3-5$ & $4-6$ & $5-6$ & $4-6$ \\
\hline \multirow{2}{*}{ МCT8 } & $F$ & 2.2519 & 8.4057 & 5.5618 & 10.4579 & 39.9546 \\
\hline & $n$ & $3-5$ & $3-5$ & $4-6$ & $5-6$ & $4-6$ \\
\hline \multirow{2}{*}{ CRYM } & $F$ & 6.9571 & 15.557 & 4.1552 & 2.9006 & 20.4657 \\
\hline & $n$ & $3-5$ & $3-5$ & $4-6$ & $5-6$ & $4-6$ \\
\hline \multirow{2}{*}{ PKM2 } & $F$ & 2.2002 & 13.6944 & 4.0911 & 0.4977 & 21.945 \\
\hline & $n$ & $3-5$ & $3-5$ & $4-6$ & $5-6$ & $4-6$ \\
\hline \multirow{2}{*}{ ALDH1 } & $F$ & 1.5814 & 4.9732 & 7.4861 & 7.6153 & 2.0967 \\
\hline & $n$ & $3-5$ & $3-5$ & $4-6$ & $5-6$ & $4-6$ \\
\hline
\end{tabular}

Statistics: one-way ANOVA, $F=F$ statistic, $n=$ sample size across stages for each gene and tissue, highlighted bold $F$ values indicate statistical significance $(P<0.05)$ across stages for that gene and tissue.

\section{Results}

\subsection{TR $\beta$ and rpL8}

To examine the potential functional significance of THTs and CTHBPs with respect to the sensitivity/responsivity of a tissue to TH, we obtained the profile of the TH-response gene TR $\beta$ for comparison with expression profiles of THTs and CTHBPs. For any one tissue, the expression of TR $\beta$ mRNA is expected to peak at the initiation of TH-dependent morphological change. Indeed, the developmental profiles of $\operatorname{TR} \beta$ for the intestine and tail follow this pattern (Fig. 1A). However, the hind limb and brain show among the earliest TH-dependent changes (NF52-54), but the TR $\beta$ peak occurred later at NF58 and NF62, respectively (Shi, 1999). Similarly, the liver expresses TH-induced urea cycle enzymes at climax of metamorphosis (NF62) (Helbing et al., 1992), but the TR $\beta$ peak occurred after that at NF64. 


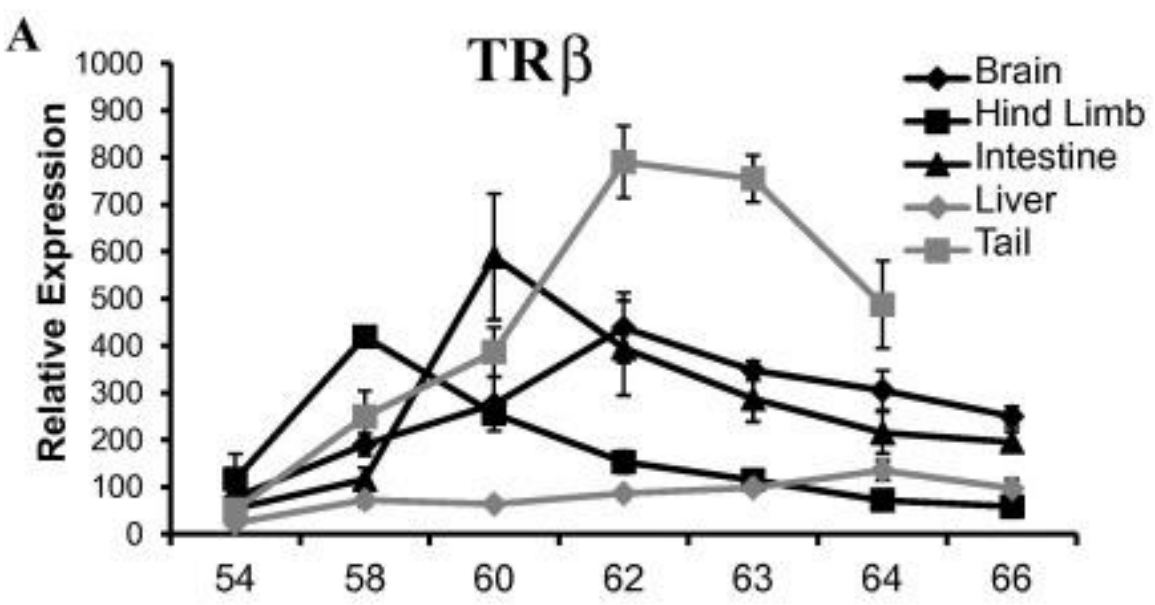

\begin{tabular}{|c|c|c|c|c|c|c|c|c|}
\hline \multirow{2}{*}{ Tissue } & \multicolumn{7}{|c|}{ Stage } & \multirow{2}{*}{$\begin{array}{c}\text { Fold Change } \\
\text { (Stages) }\end{array}$} \\
\cline { 2 - 9 } & 54 & 58 & 60 & 62 & 63 & 64 & 66 & 5.67 \\
\hline Brain & $\mathrm{A}$ & $\mathrm{AB}$ & $\mathrm{ABC}$ & $\mathrm{C}$ & $\mathrm{BC}$ & $\mathrm{ABC}$ & $\mathrm{ABC}$ & $\mathrm{A}$ \\
\hline Hind Limb & $\mathrm{AB}$ & $\mathrm{D}$ & $\mathrm{C}$ & $\mathrm{B}$ & $\mathrm{AB}$ & $\mathrm{A}$ & $\mathrm{A}$ & 3.6 \\
\hline Intestine & $\mathrm{A}$ & $\mathrm{AB}$ & $\mathrm{C}$ & $\mathrm{BC}$ & $\mathrm{ABC}$ & $\mathrm{ABC}$ & $\mathrm{ABC}$ & 10.82 \\
\hline Liver & $\mathrm{A}$ & $\mathrm{AB}$ & $\mathrm{AB}$ & $\mathrm{BC}$ & $\mathrm{BC}$ & $\mathrm{C}$ & $\mathrm{BC}$ & 5.69 \\
\hline Tail & $\mathrm{A}$ & $\mathrm{AB}$ & $\mathrm{B}$ & $\mathrm{D}$ & $\mathrm{CD}$ & $\mathrm{BC}$ & & 15.27 \\
\hline
\end{tabular}

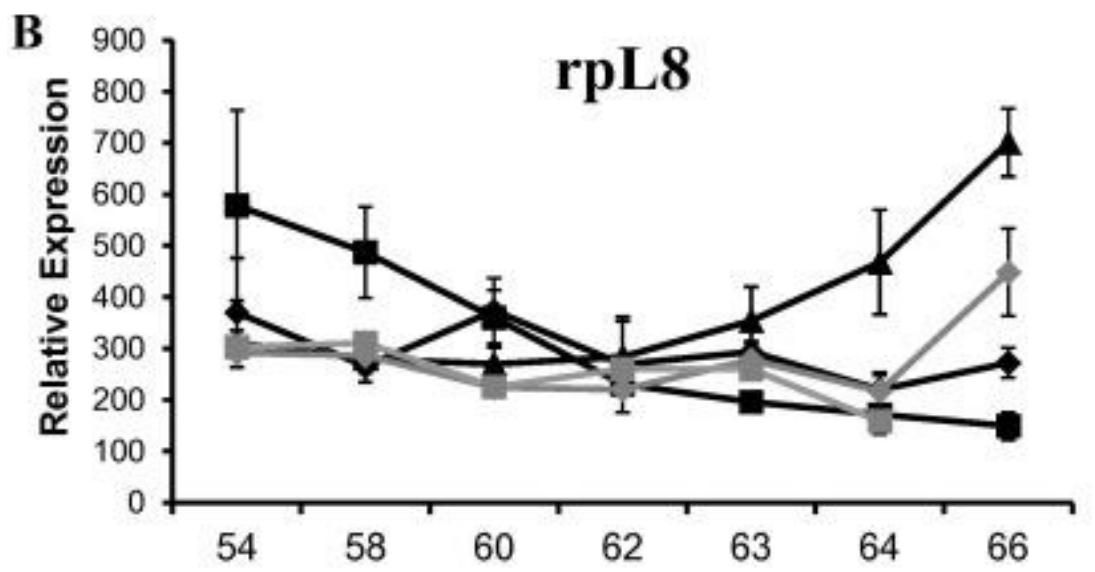

\begin{tabular}{|c|c|c|c|c|c|c|c|}
\hline \multirow{2}{*}{ Tissue } & \multicolumn{7}{|c|}{ Stage } \\
\cline { 2 - 8 } & 54 & 58 & 60 & 62 & 63 & 64 & 66 \\
\hline Brain & - & - & - & - & - & - & - \\
\hline Hind Limb & $\mathrm{AB}$ & $\mathrm{A}$ & $\mathrm{AB}$ & $\mathrm{B}$ & $\mathrm{B}$ & $\mathrm{B}$ & $\mathrm{B}$ \\
\hline Intestine & $\mathrm{AB}$ & $\mathrm{A}$ & $\mathrm{A}$ & $\mathrm{A}$ & $\mathrm{AB}$ & $\mathrm{AB}$ & $\mathrm{B}$ \\
\hline Liver & $\mathrm{AB}$ & $\mathrm{AB}$ & $\mathrm{A}$ & $\mathrm{A}$ & $\mathrm{AB}$ & $\mathrm{A}$ & $\mathrm{B}$ \\
\hline Tail & $\mathrm{A}$ & $\mathrm{A}$ & $\mathrm{BC}$ & $\mathrm{AB}$ & $\mathrm{AB}$ & $\mathrm{C}$ & \\
\hline
\end{tabular}

Fig. 1. Quantification of TR $\beta$ and rpL8 mRNA among tissues during natural metamorphosis. Tadpoles of Xenopus tropicalis were staged, tissues were harvested (hind limb, brain, intestine, liver, tail), and total RNA and cDNA were prepared. Expression of TR $\beta$ (A) and rpL8 (B) were measured by quantitative PCR. Standard error is indicated with a bar at each time point, $n=3-6$. Post hoc pair wise comparisons (TukeyKramer) were conducted within tissues across developmental stages, and letters in the tables represent significance groups within tissues. Gray/bold cells in the table indicate stage at peak TR $\beta$ expression for each tissue. The black box indicates absence of data for the tail, which has resorbed completely by NF66. Numbers in the tables represent fold changes in TR $\beta$ expression comparing the levels between NF54 and stage of the TR $\beta$ peak for each tissue.

As reported previously (Dhorne-Pollet et al., 2013; Duarte-Guterman et al., 2010; Sindelka et al., 2006), we found that rpL8 values do not remain constant across stages or tissues (Fig. 1B). Thus, analyses of TR $\beta$ and the THTs and CTHBPs were not normalized to a housekeeping gene to avoid introducing undesirable biases. Rather, each cDNA 
sample used for qPCR was synthesized using the same amount of total RNA, and relative expression levels were calculated as the average of 3-6 samples per stage and tissue.

\subsection{TH transporters}

\subsubsection{LAT1}

Comparison of expression across tissues revealed that brain expressed significantly more LAT1 than the other tissues and that only hind limb and intestine had significantly different expression levels across stages (Fig. 2A, Table 3). For the intestine, LAT1 expression was similar across stages until a 16-fold increase at NF66 compared to NF54 but showed no significant increase at the stage of peak intestinal TR $\beta$ expression. In the hind limb, high levels of LAT1 expression corresponded to the peak in TR $\beta$ expression, with nearly 6 -fold expression level change across stages.

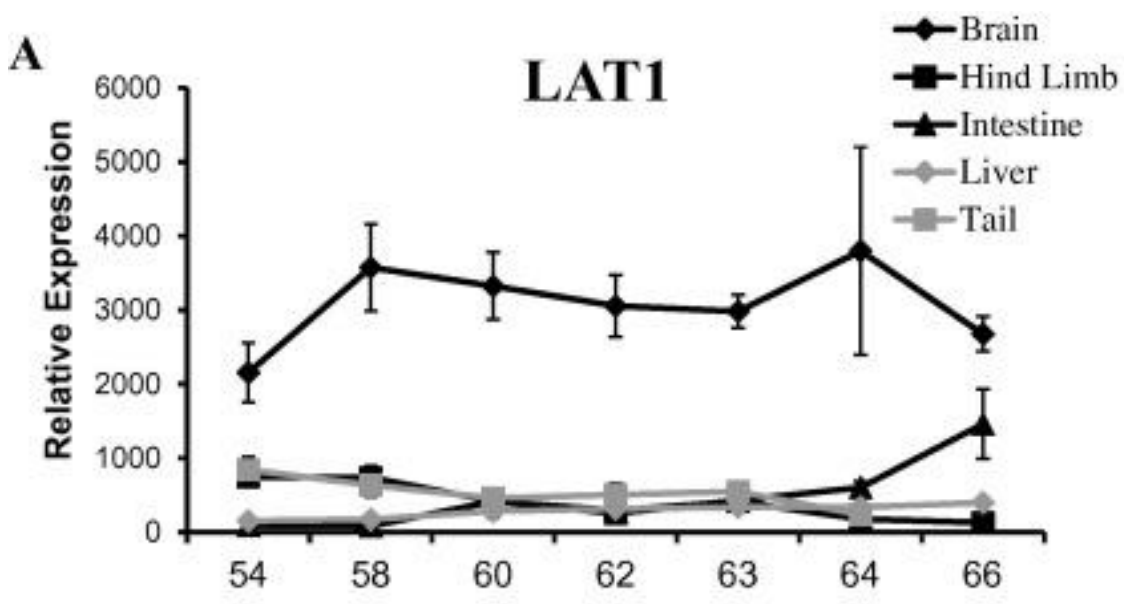

\begin{tabular}{|c|c|c|c|c|c|c|c|c|}
\hline \multirow{2}{*}{ Tissue } & \multicolumn{7}{|c|}{ Stage } & \multirow{2}{*}{$\begin{array}{c}\text { Fold Change } \\
\text { (Stages) }\end{array}$} \\
\cline { 2 - 9 } & 54 & 58 & 60 & 62 & 63 & 64 & 66 & $1.76(54$ to 64$)$ \\
\hline Brain & - & - & - & - & - & - & - & $1.76(4)(54$ to 66$)$ \\
\hline Hind Limb & $\mathrm{AB}$ & $\mathrm{A}$ & $\mathrm{ABC}$ & $\mathrm{BC}$ & $\mathrm{ABC}$ & $\mathrm{C}$ & $\mathrm{ABC}$ & $-5.744(54$ to 66$)$ \\
\hline Intestine & $\mathrm{A}$ & $\mathrm{A}$ & $\mathrm{A}$ & $\mathrm{A}$ & $\mathrm{A}$ & $\mathrm{A}$ & $\mathrm{B}$ & $16.24(5)$ \\
\hline Liver & - & - & - & - & - & - & - & $2.6(54$ to 66$)$ \\
\hline Tail & - & - & - & - & - & - & & $-3.57(54$ to 64$)$ \\
\hline
\end{tabular}

B

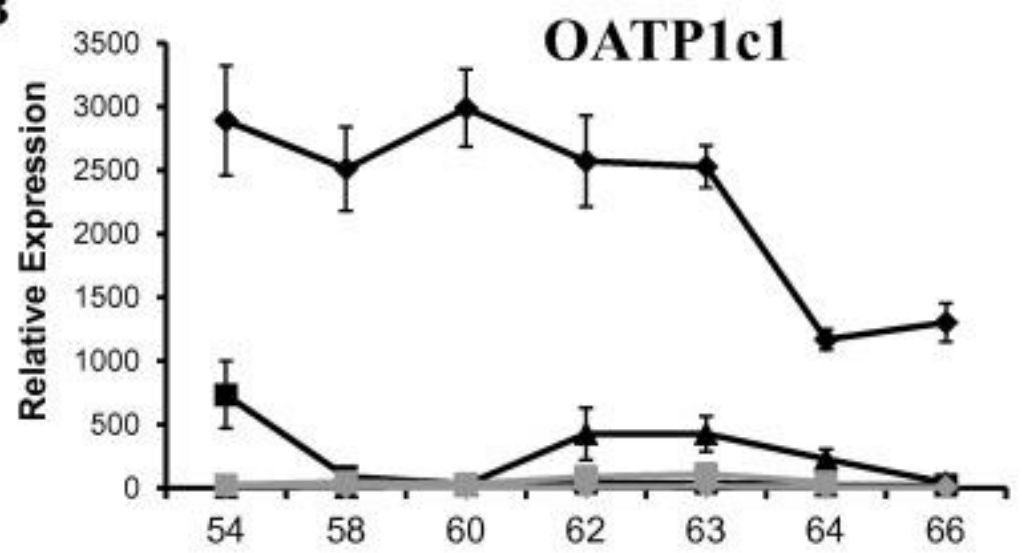

\begin{tabular}{|c|c|c|c|c|c|c|c|c|}
\hline \multirow{2}{*}{ Tissue } & \multicolumn{7}{|c|}{ Stage } & Fold Change \\
\cline { 2 - 8 } & 54 & 58 & 60 & 62 & 63 & 64 & 66 & (Stages) \\
\hline Brain & $\mathrm{A}$ & $\mathrm{AB}$ & $\mathrm{A}$ & $\mathrm{A}$ & $\mathrm{A}$ & $\mathrm{B}$ & $\mathrm{B}$ & $1.03(54$ to 60$)$ \\
\hline Hind Limb & $\mathrm{A}$ & $\mathrm{B}$ & $\mathrm{B}$ & $\mathrm{B}$ & $\mathrm{B}$ & $\mathrm{B}$ & $\mathrm{B}$ & $-35.08(54$ to 66$)$ \\
\hline Intestine & - & - & - & - & - & - & - & $48.39(54$ to 62$)$ \\
\hline Liver & $\mathrm{A}$ & $\mathrm{ABC}$ & $\mathrm{C}$ & $\mathrm{ABC}$ & $\mathrm{AB}$ & $\mathrm{BC}$ & $\mathrm{ABC}$ & $-2.10(54$ to 66$)$ \\
\hline Tail & $\mathrm{A}$ & $\mathrm{AB}$ & $\mathrm{AB}$ & $\mathrm{AB}$ & $\mathrm{B}$ & $\mathrm{AB}$ & & $4.46(54$ to 63$)$ \\
\hline
\end{tabular}


C

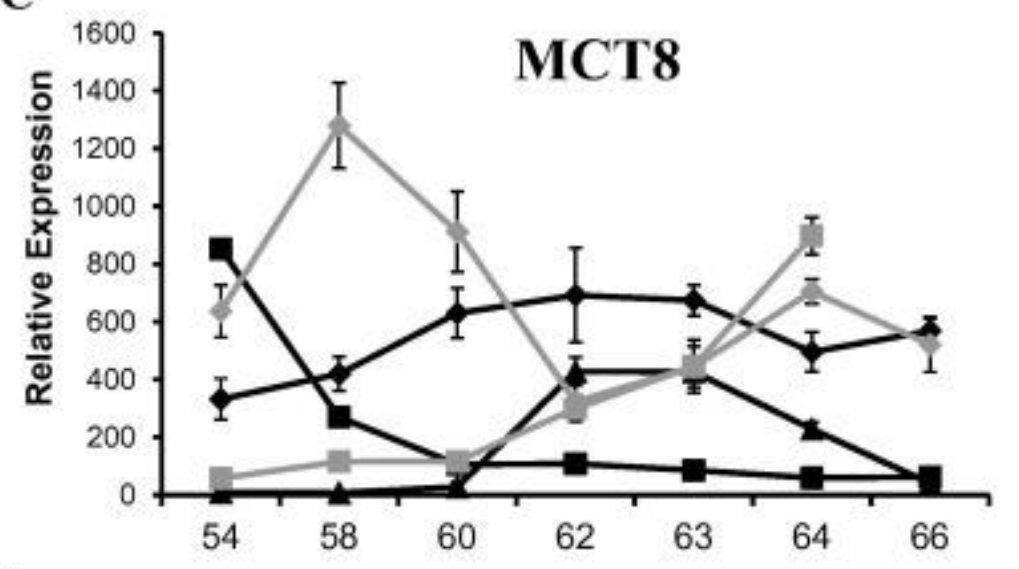

\begin{tabular}{|c|c|c|c|c|c|c|c|c|}
\hline \multirow{2}{*}{ Tissue } & \multicolumn{7}{|c|}{ Stage } & \multirow{2}{*}{$\begin{array}{c}\text { Fold Change } \\
\text { (Stages) }\end{array}$} \\
\cline { 2 - 9 } & 54 & 58 & 60 & 62 & 63 & 64 & 66 & \\
\hline Brain & - & - & - & - & - & - & - & $2.09(54$ to 62$)$ \\
\hline Hind Limb & $\mathrm{A}$ & $\mathrm{B}$ & $\mathrm{C}$ & $\mathrm{C}$ & $\mathrm{C}$ & $\mathrm{C}$ & $\mathrm{C}$ & $-13.75(54$ to 66$)$ \\
\hline Intestine & $\mathrm{A}$ & $\mathrm{A}$ & $\mathrm{ABC}$ & $\mathrm{C}$ & $\mathrm{BC}$ & $\mathrm{ABC}$ & $\mathrm{AB}$ & $7.39(54$ to 62$)$ \\
\hline Liver & $\mathrm{AB}$ & $\mathrm{C}$ & $\mathrm{BC}$ & $\mathrm{A}$ & $\mathrm{A}$ & $\mathrm{AB}$ & $\mathrm{AB}$ & $2.01(54$ to 58$)$ \\
\hline Tail & $\mathrm{A}$ & $\mathrm{AB}$ & $\mathrm{AB}$ & $\mathrm{BC}$ & $\mathrm{C}$ & $\mathrm{D}$ & & $15.61(54$ to 64$)$ \\
\hline
\end{tabular}

D

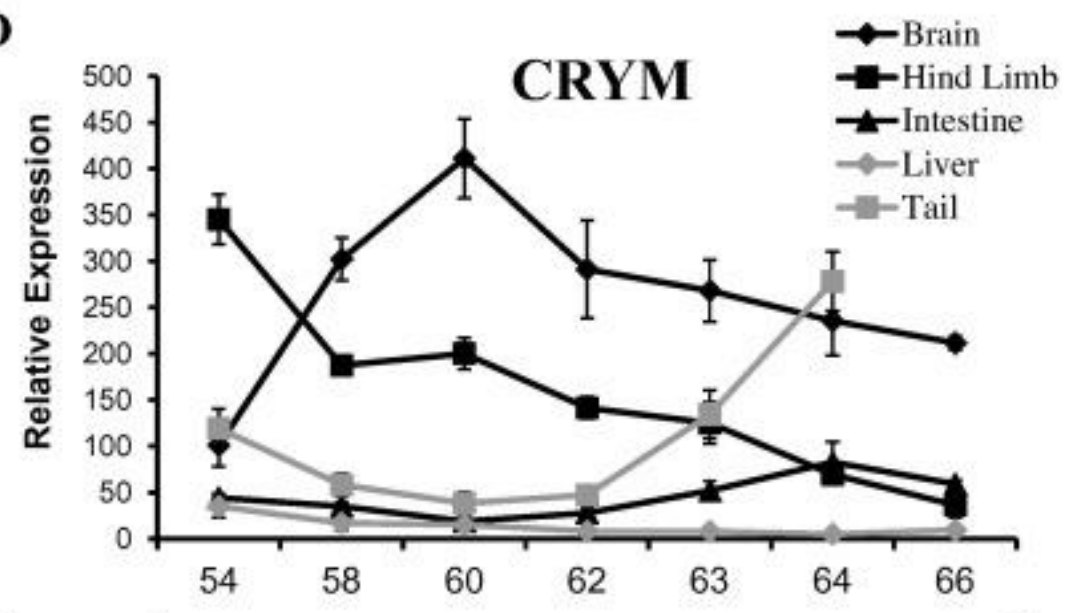

\begin{tabular}{|c|c|c|c|c|c|c|c|c|}
\hline \multirow{2}{*}{ Tissue } & \multicolumn{7}{|c|}{ Stage } & \multirow{2}{*}{$\begin{array}{c}\text { Fold Change } \\
\text { (Stages) }\end{array}$} \\
\cline { 2 - 8 } & 54 & 58 & 60 & 62 & 63 & 64 & 66 & \\
\hline Brain & $\mathrm{A}$ & $\mathrm{BC}$ & $\mathrm{C}$ & $\mathrm{BC}$ & $\mathrm{ABC}$ & $\mathrm{AB}$ & $\mathrm{AB}$ & $4.07(54$ to 60$)$ \\
\hline Hind Limb & $\mathrm{A}$ & $\mathrm{BC}$ & $\mathrm{B}$ & $\mathrm{BC}$ & $\mathrm{CD}$ & $\mathrm{DE}$ & $\mathrm{E}$ & $-9.51(54$ to 66$)$ \\
\hline Intestine & $\mathrm{AB}$ & $\mathrm{A}$ & $\mathrm{A}$ & $\mathrm{A}$ & $\mathrm{AB}$ & $\mathrm{B}$ & $\mathrm{AB}$ & $1.87(54$ to 64$)$ \\
\hline Liver & $\mathrm{A}$ & $\mathrm{AB}$ & $\mathrm{AB}$ & $\mathrm{B}$ & $\mathrm{B}$ & $\mathrm{B}$ & $\mathrm{AB}$ & $-7.16(54$ to 64$)$ \\
\hline Tail & $\mathrm{AB}$ & $\mathrm{AB}$ & $\mathrm{A}$ & $\mathrm{A}$ & $\mathrm{B}$ & $\mathrm{C}$ & & $2.33(54$ to 64$)$ \\
\hline
\end{tabular}



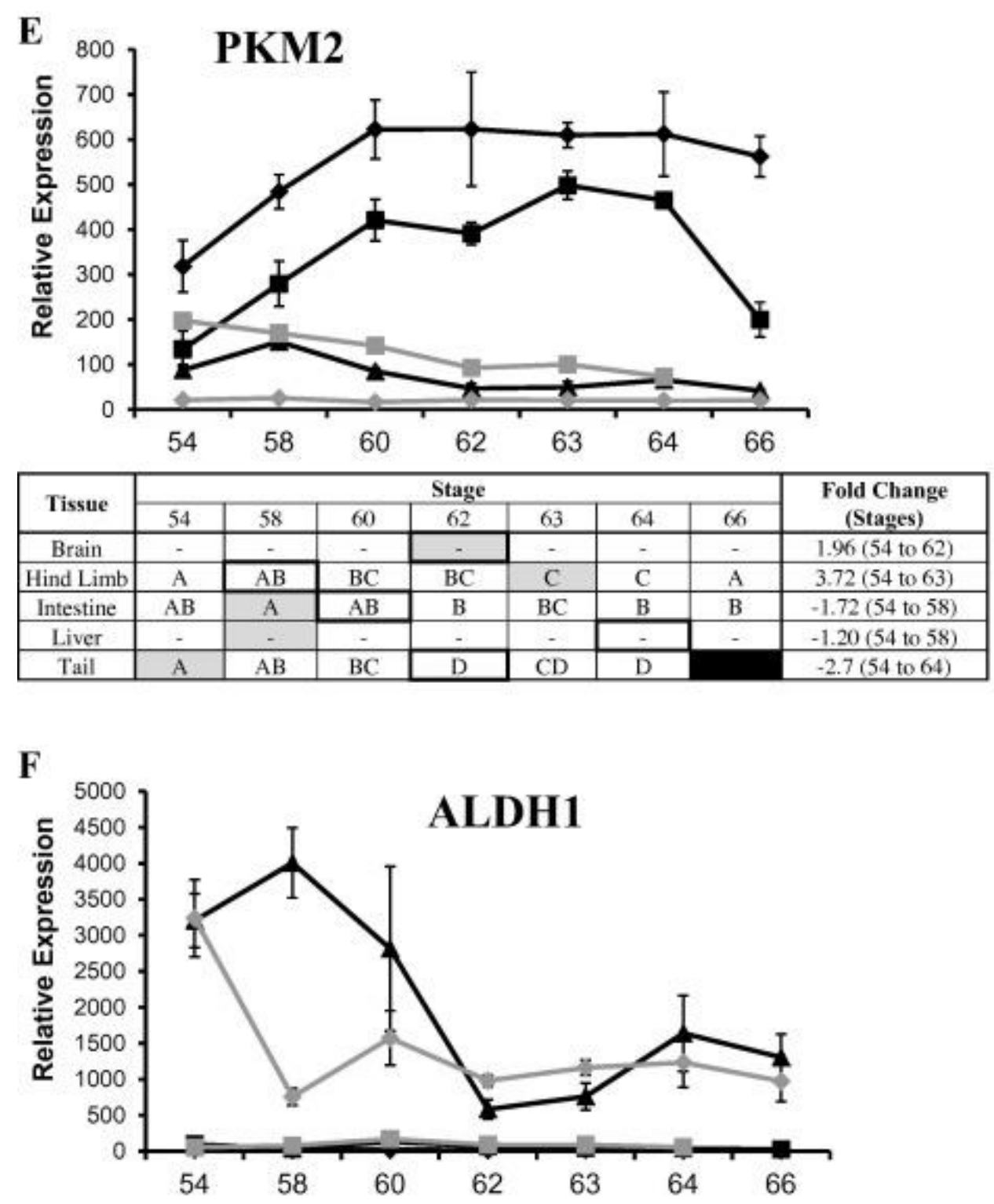

\begin{tabular}{|c|c|c|c|c|c|c|c|c|}
\hline \multirow{2}{*}{ Tissue } & \multicolumn{7}{|c|}{ Stage } & \multirow{2}{*}{$\begin{array}{c}\text { Fold Change } \\
\text { (Stages) }\end{array}$} \\
\cline { 2 - 9 } & 54 & 58 & 60 & 62 & 63 & 64 & 66 & 1.09(54 to 63$)$ \\
\hline Brain & - & - & - & - & - & - & - & A \\
\hline Hind Limb & $\mathrm{AB}$ & $\mathrm{A}$ & $\mathrm{B}$ & $\mathrm{AB}$ & $\mathrm{A}$ & $\mathrm{A}$ & $\mathrm{A}$ & $1.35(54$ to 60$)$ \\
\hline Intestine & $\mathrm{AB}$ & $\mathrm{A}$ & $\mathrm{AB}$ & $\mathrm{C}$ & $\mathrm{C}$ & $\mathrm{BC}$ & $\mathrm{BC}$ & $1.25(54$ to 58$)$ \\
\hline Liver & $\mathrm{A}$ & $\mathrm{B}$ & $\mathrm{B}$ & $\mathrm{B}$ & $\mathrm{B}$ & $\mathrm{B}$ & $\mathrm{B}$ & $-3.33(54$ to 66$)$ \\
\hline Tail & - & - & - & - & - & - & & $3.10(54$ to 60$)$ \\
\hline
\end{tabular}

Fig. 2. Quantification of THT and CTHBP mRNAs among tissues during natural metamorphosis in Xenopus tropicalis. The same samples and statistical analyses were used as in Fig. 1. For the THTs, LAT1, OATP1c1 and MCT8 (A-C) and CTHBPs, CRYM, PKM2 and ALDH1 (D-F), the peak in mRNA expression is indicated by a gray box for each tissue. TR $\beta$ peaks are indicated by bold boxes to compare timing of expression peaks with the TH signaling genes.

\subsubsection{OATP1c1}

Expression levels of OATP1c1 varied across stages for each tissue except intestine (Fig. 2B, Table 3). Like LAT1, OATP1c1 was highly expressed in the brain compared to the other tissues and remained high through NF63, followed by a 2 -fold decrease. In the hind limb, OATP1c1 was initially high at the time of limb growth initiation then showed a 35-fold decrease at NF58 and then remained low. Liver and tail maintained relatively low levels of OATP1c1 expression throughout the larval period. In no tissue did an OATP1c1 peak match the TR $\beta$ expression peak for that tissue, though the hind limb and tail OATP1c1 peaks were one stage before the corresponding TR $\beta$ peak. 


\subsection{3. $\mathrm{MCT} 8$}

Expression levels of MCT8 varied across stages for each tissue except brain (Fig. 2C, Table 3). The peaks in MCT8 expression roughly matched the stage of transformation in hind limb, intestine, and tail but not in liver. The fold change expression from NF stage 54 to expression peak varied among tissues with the greatest fold change in the tail (16-fold increase) and hind limb (14-fold decrease), followed by the intestine (7-fold increase) and liver (2-fold decrease).

\subsection{Cytosolic TH binding proteins}

\subsubsection{CRYM}

Expression of CRYM changed significantly with distinct profiles across stages for each tissue (Fig. 2D, Table 3). CRYM expression peaks for brain and hind limb occurred one stage before the TR $\beta$ peak, but had the opposite pattern in intestine. CRYM expression increased in tail during tail resorption. Overall expression levels in the liver were low compared to other tissues.

\subsubsection{PKM2}

The expression profile of PKM2 significantly increased in hind limbs and decreased in intestine and tail (Fig. 2E, Table 3), and these changes were inversely correlated with the corresponding TR $\beta$ peak in hind limb and tail. Brain and liver showed no significant change in PKM2 expression during the stages tested.

\subsubsection{ALDH1}

Intestine and liver had high expression levels that declined as development progressed, compared to the other tissues, which had low and usually non-significant changes across development (Fig 2F, Table 3). The decreases in ALDH1 expression coincided with the timing of metamorphic changes in liver and intestine and were inversely related to the peak in TR $\beta$ expression.

\subsection{In-vivo gene function study in tadpole tail muscle}

To test direct effects of TH signaling proteins in TH-dependent development in vivo, plasmids encoding LATI, PKM2, MCT8, CRYM, MCT8 + CRYM, or control DsRed2 fluorescent protein under transcriptional control of the ubiquitous promoter CMV (cytomegalovirus) were injected into tadpole tail muscle cells using somatic gene transfer system (De Luze et al., 1993; Sachs et al., 2004) (Fig. 3A). Fluorescent protein expression marked cells that received the plasmids in order to monitor their cell disappearance by daily monitoring using a fluorescence microscope (Fig. 3B). A set of tadpoles was used to test the overexpression of THTs and CTHBPs on day 5, and qPCR measurements of mRNA levels confirmed their overexpression in injected tails (Suppl. Table 2). As expected with the low dose of T3, the amount of cell disappearance in control-injected tails was slightly more in the $2 \mathrm{nM} \mathrm{T3}$ compared to the $0 \mathrm{nM} \mathrm{T3}$ treatment (Fig. 4, compare solid and dashed lines lacking symbols in all the panels). Also, substantial variation was observed among individual tadpoles in most of the experiments, but treatment day had low variation across experiments (Table 4, see Random Effects sections of table). 
A
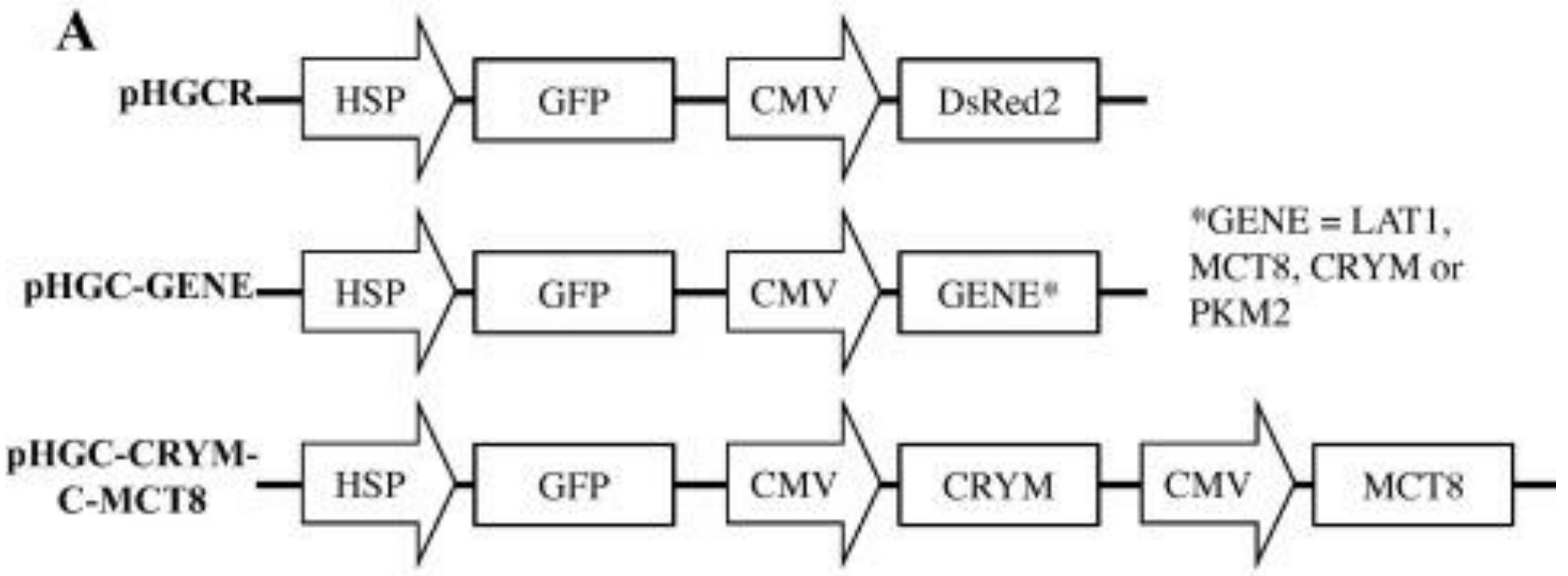

B

Day 5

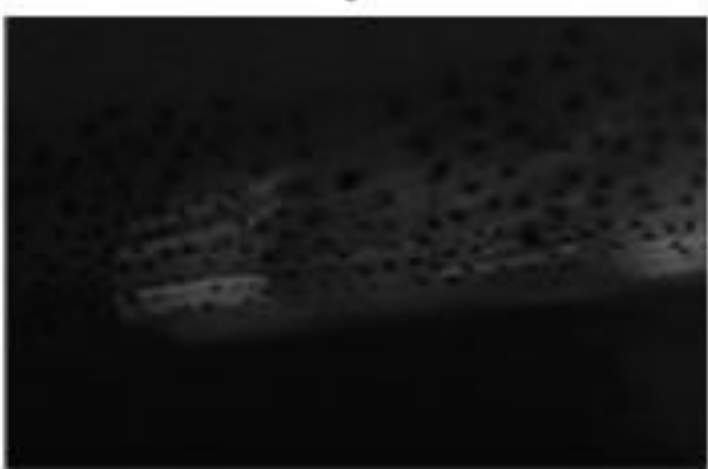

- T3

$+\mathrm{T} 3$

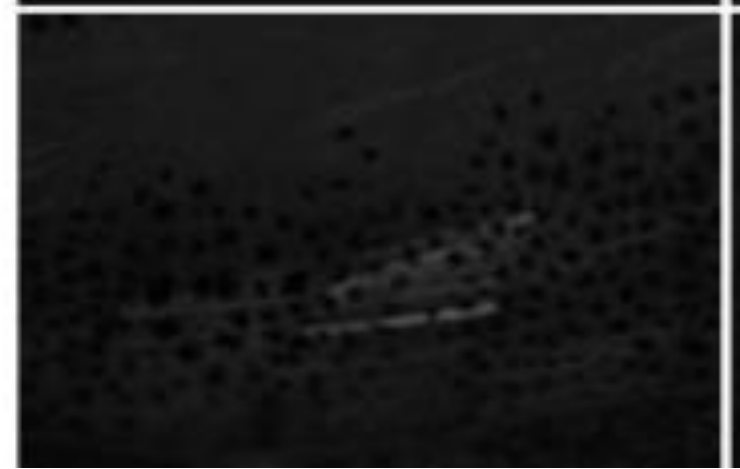

Day 12
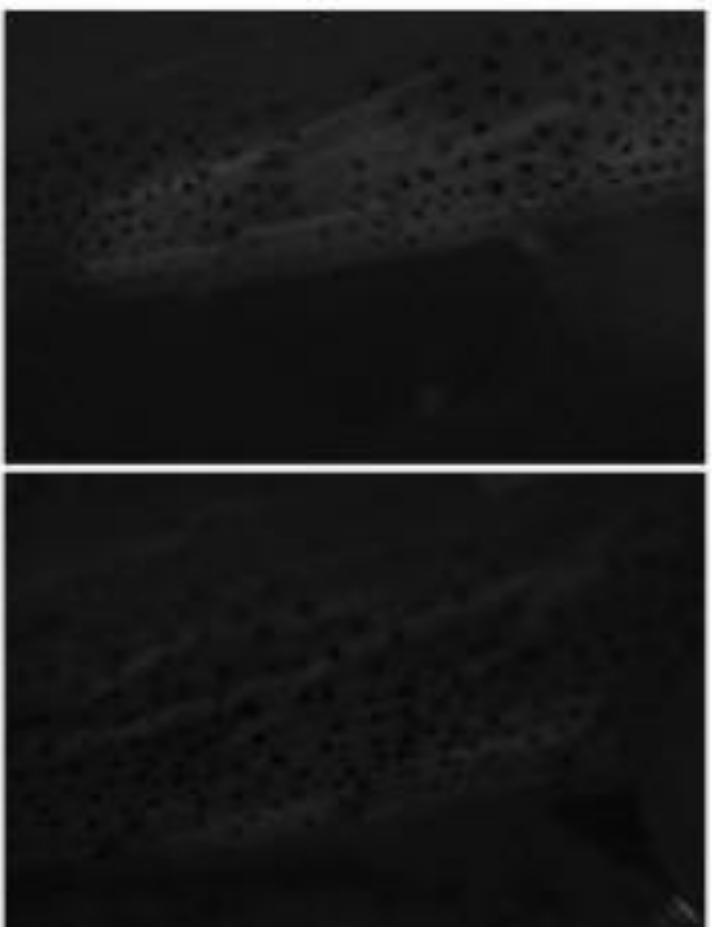

Fig. 3. Diagrams of constructs used to overexpress target genes and exemplar images of tail muscle cells. (A) Expression of green fluorescent protein (GFP) was under the control of the heat shock-inducible promoter (HSP), and expression of DsRed2 and genes encoding THTs, CTHBPs was under the control of the ubiquitous cytomegalovirus (CMV) promoter. GFP was used as a marker to monitor cell disappearance. (B) Tails injected with the pHGC-LAT1 construct were treated with T3 (0 or $2 \mathrm{nM})$ starting on Day 2, and imaged on treatment day 5 and 12. Muscle cells expressing the transgenes appear as horizontal green rods, and their disappearance has occurred to a greater extent in the T3treated animals. 

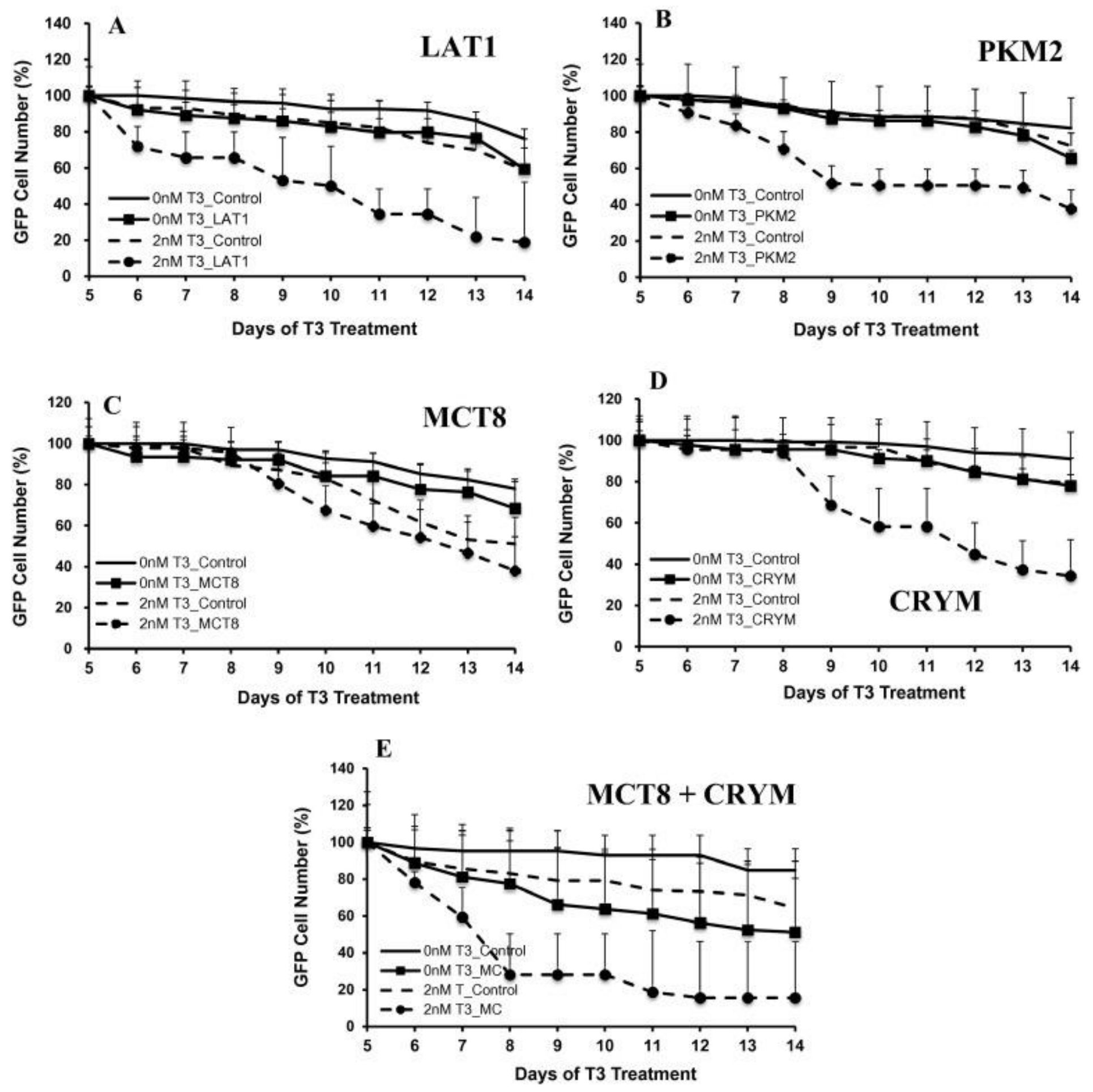

Fig. 4. Effect of THT and CTHBP overexpression in TH-dependent tail muscle cell disappearance. Overexpression of LAT1 (A), PKM2 (B), MCT8 (C), CRYM (D), and MCT8 + CRYM (E) was achieved by injection of expression plasmids into tail muscle at NF56. Expression cassettes for a fluorescent protein on the same plasmid enabled observation of muscle cells overexpressing a THT or CTHBP. Injection on the opposite side of the tail of a plasmid that only expresses fluorescent proteins served as the control for the absence of overexpressed THT or CTHBP. Injected tadpoles were treated with 0 or $2 \mathrm{nM}$ T3 daily for 14 days, and counts of muscle cells expressing fluorescent proteins were conducted daily from Day 5 to Day 14. Cell disappearance was quantified as the percent of the number of fluorescent cells on a particular day compared to the number of fluorescent cells on Day 5. The effect of T3 was to reduce the number of fluorescent cells to $60-80 \%$, and overexpression of THTs or CTHBPs in the presence of T3 reduced the percent of fluorescent cells to $20-40 \%$ depending on the gene. In the absence of T3, percent of fluorescent cells remained above $80 \%$ in the controls and ranged from $60 \%$ to $80 \%$ across overexpressed THTs and CTHBPs. Error bars represent standard deviation. 
Table 4. Analysis of fixed and random effects on the rate of cell disappearance in tadpole tail muscle after THT and CTHBP plasmid injection.

\begin{tabular}{|c|c|c|c|c|c|c|c|c|c|}
\hline & & \multicolumn{2}{|l|}{ LAT1 } & \multicolumn{3}{|l|}{ MCT8 } & \multicolumn{3}{|l|}{ PKM2 } \\
\hline & & $x^{2}$ & $P$ value & $x^{2}$ & df & $P$ value & $x^{2}$ & df & $P$ value \\
\hline \multirow[t]{5}{*}{ Fixed effect } & Null deviance & 795.97 & 139 & 852.56 & 6199 & & 1102.1 & 199 & \\
\hline & T3 & 17.62 & $<0.05$ & 14.7 & 2 & $<0.05$ & 10.48 & 2 & $<0.05$ \\
\hline & Injected gene & 175.17 & $<0.05$ & 31.13 & 2 & $<0.05$ & 14.77 & 2 & $<0.05$ \\
\hline & T3 + Injected gene & 8.86 & $<0.05$ & 2.94 & 1 & $>0.05$ & 4.81 & 1 & $<0.05$ \\
\hline & & \multicolumn{8}{|c|}{ Variance \pm Standard deviation } \\
\hline \multirow[t]{4}{*}{ Random effect } & Tadpole & \multicolumn{2}{|c|}{$39.69 \pm 6.30$} & \multicolumn{3}{|c|}{$51.39 \pm 7.17$} & \multicolumn{3}{|c|}{$17.44 \pm 4.18$} \\
\hline & Treatment day & \multicolumn{2}{|c|}{$0.14 \pm 0.38$} & \multicolumn{2}{|c|}{$0.28 \pm 0.53$} & & \multicolumn{3}{|c|}{$0.12 \pm 0.35$} \\
\hline & & & \multicolumn{3}{|l|}{ CRYM } & \multicolumn{4}{|c|}{ MCT8 + CRYM } \\
\hline & & & $x^{2}$ & df & $P$ value & $x^{2}$ & & $d f$ & $P$ value \\
\hline \multirow[t]{5}{*}{ Fixed effect } & \multicolumn{2}{|l|}{ Null deviance } & 960.68 & \multicolumn{2}{|l|}{159} & \multicolumn{2}{|c|}{1036.1} & 99 & \\
\hline & \multicolumn{2}{|l|}{ T3 } & 35.71 & 2 & $<0.05$ & \multicolumn{2}{|l|}{5.23} & 2 & $>0.05$ \\
\hline & \multicolumn{2}{|l|}{ Injected gene } & 262.63 & 2 & $<0.05$ & \multicolumn{2}{|c|}{476.92} & 2 & $<0.05$ \\
\hline & \multicolumn{2}{|c|}{ T3 + Injected gene } & 13.19 & 1 & $<0.05$ & \multicolumn{2}{|l|}{0.11} & 1 & $>0.05$ \\
\hline & & & \multicolumn{6}{|c|}{ Variance \pm Standard deviation } & \\
\hline \multirow[t]{2}{*}{ Random effect } & \multicolumn{2}{|l|}{ Tadpole } & \multicolumn{3}{|c|}{$48.23 \pm 6.95$} & \multicolumn{3}{|c|}{$6.31 \pm 3.13$} & \\
\hline & \multicolumn{2}{|l|}{ Treatment day } & \multicolumn{3}{|c|}{$0.23 \pm 0.49$} & \multicolumn{3}{|c|}{$0.09 \pm 0.28$} & \\
\hline
\end{tabular}

Bold values indicate significance at a level of $\alpha<0.05$.

LAT1, PKM2, and CRYM had similar patterns of cell disappearance among treatments (Fig.4A, B and D). In the absence of T3, overexpression of these genes had a similar effect on muscle cell disappearance compared to the control muscle cells injected on the opposite side of the tail. However, in the presence of T3, cell disappearance was greater in tails with overexpression of these genes compared to control-injected tails. The generalized linear mixed model statistical analysis showed that all three fixed effects, i.e., Gene, TH treatment, and Gene $\times$ TH interaction had significant effects on cell disappearance in tadpole tail muscle (Table 4). Thus, LAT1, PKM2, and CRYM overexpression increased the amount of cell disappearance induced by T3. 
For MCT8, the rate of cell disappearance in the MCT8-injected tails paralleled that in the control tails in the absence and presence of T3 (Fig. 4C). The generalized linear mixed model statistical analysis showed that the fixed effects, Gene and TH treatment but not Gene $\times$ TH interaction, had significant effects on cell disappearance (Table 4). Thus, MCT8 had a slight but significant effect on cell disappearance but did not increase T3-induced cell disappearance.

Co-overexpression of MCT8 and CRYM greatly increased rate of tail muscle cell disappearance in the absence and presence of exogenous T3 treatment (Fig. 4E). The generalized linear mixed model showed that only the fixed effect, Gene and not TH treatment or Gene $\times$ TH interaction, had a significant effect on cell disappearance (Table 4). Thus, MCT8 + CRYM significantly increased cell disappearance but the high variation in the experiment precluded the ability to detect a statistically significant effect of $\mathrm{TH}$ or of a Gene $\times \mathrm{TH}$ interaction.

\section{Discussion}

The THT and CTHBP expression patterns observed were consistent with those in previous studies examining mRNA profiles, in cases where there was overlap among studies in developmental stages and organs (Connors et al., 2010; Shi et al., 1994). To evaluate their potential contribution to the timing of tissue transformation, the THT and CTHBP expression profiles were compared to those of TR $\beta$. TR $\beta$ autoinduction is a sensitive molecular indicator of TH signaling that presages morphological transformation in many tissues (Tata, 2000). Indeed, the TR $\beta$ expression profile peaked at developmental stages coinciding with initiation of metamorphic changes in brain, intestine, and tail. However, hind limb TR $\beta$ expression peaked at NF58, even though TH-dependence of hind limb development begins at NF54. The explanation for this discrepancy is not clear, but previous RT-qPCR data for hind limb TR $\beta$ expression showed a similar developmental profile (Wang et al., 2008). Also, liver TR $\beta$ mRNA levels gradually increased to a low peak at NF64, but the explanation is unknown for the lack of correspondence with TH-dependent induction of urea cycle enzymes, which occurs at climax of metamorphosis (Atkinson et al., 1996).

For any given tissue, we hypothesized that a high expression level of a THT potentially involved in tissue sensitivity to TH would correspond to or immediately precede the TR $\beta$ peak and initiation of metamorphic change. Our data show that expression peaks for LAT1 in hind limb, OATP1c1 in hind limb and brain, and MCT8 in hind limb and tail corresponded to the TR $\beta$ expression peaks, thereby strengthening the link between THT expression and timing of tissue transformation in those cases. For CTHBPs, we expected a trough for CTHBPs at the TR $\beta$ peak if they act to sequester TH in the cytoplasm inhibiting TH movement to the nucleus. On the other hand, CTHBPs may act as a delivery system from the cell surface to the nucleus, in which case the CTHBP and TR $\beta$ peaks may correspond. The pattern of CRYM mRNA expression was consistent with that of a delivery system in hind limb, brain, and tail. Expression of PKM2 in hind limb, intestine, and tail and ALDH1 in intestine was consistent with a sequestering role. However, for most tissues, expression of THTs and CTHBPs either was not significant across stages or did not correspond to the TR $\beta$ peak, signifying a lack of evidence one way or the other that they play a role in tissue asynchrony in those tissues.

Several caveats are important when inferring biological significance of mRNA expression levels for tissue sensitivity and developmental asynchrony. Importantly, even though mRNA expression levels are suggestive of the degree of involvement in tissue sensitivity, protein expression and activity levels, which may or may not correspond to mRNA levels, directly determine the effect of THTs and CTHBPs. Indeed, our ALDH1 mRNA expression pattern did not correspond to T3 binding activity which was previously shown to increase gradually in liver and intestine during metamorphosis (Yamauchi and Tata, 1997). Also, our measurements using whole organs such as the brain may obscure significant expression changes important in subsets of cells for tissue sensitivity. Furthermore, lack of correspondence between THT/CTHBP and TR $\beta$ mRNA expression we observed does not preclude participation in control of tissue asynchrony because even steady levels of THT/CTHBP expression may trigger tissue transformation at a particular point in time corresponding to a threshold level of the rising TH titer. Thus, though suggestive, mRNA expression patterns and levels by themselves are not definitive evidence for a role in regulation of tissue sensitivity to $\mathrm{TH}$ and developmental asynchrony. 
Functional studies provide a complementary approach to assess THT or CTHBP involvement in TH signaling. We used a tail injection assay involving a standard form of GFP whose protein lasts for weeks in vivo (Kerney et al., 2012) to determine the effect of THT or CTHBP overexpression on metamorphic change, i.e., TH-dependent tail muscle cell disappearance. The loss of GFP signal from a muscle cell within $24 \mathrm{~h}$ is considered strong evidence of cell death (Hollar et al., 2011; Nakajima et al., 2012). Such cell disappearance observed is likely via cell death by apoptosis because the cells disappear within one day rather than gradually decreasing in GFP fluorescence and because TH is well known to induce apoptosis in tail muscle cells (Nakajima and Yaoita, 2003). From the above expression studies, endogenous levels of THTs and CTHBPs in the tail were likely to be low favoring the chance that tail muscle would be a good test tissue. Also, we used a dose of T3 close to the threshold level of sensitivity for the tail, which favors detecting an increase in response to TH. Decreased responses to TH potentially due to CTHBPs are less likely to be measured. The multiple protein activities of THTs (transport amino acids in addition to TH) and CTHBPs (have enzymatic activity in addition to binding $\mathrm{TH}$ ) complicate interpretation, such that any increase in cell death may not be via TH signaling but due to altered amino acid transport or enzyme activity. However, lack of induction of cell disappearance by THT or CTHBP overexpression in the absence of T3 would argue against toxicity or alteration of cell function causing cell death.

For LAT1, consistent with in vitro assays measuring TH gene regulation (Ritchie et al., 2003; Shi et al., 2002), LAT1 increased the rate of tail cell disappearance in a T3-dependent manner suggesting that LAT1 can increase TH signaling in vivo. Alternate interpretations have not been formally ruled out that the increased amino acid transport may lead to cell disappearance by an unknown mechanism independent of T3 transport. Use of the related transporter y + LAT1 that transports an overlapping spectrum of amino acids as LAT1 but without the T3 transport (Hennemann, 2001) may formally rule out the alternate explanation. The positive correlations of LAT1 expression with hind limb, tail, and intestine remodeling may signify a role in TH signaling especially in those tissues, but may also reflect a greater need for amino acid transport during tissue remodeling. Indeed, LAT1 was highly expressed after metamorphic climax (NF stage 66) when intestine may require amino acid transport in the intestine. Teasing apart the impact of one role versus the other for LAT1 is a challenge for future experiments.

In contrast to LAT1, overexpression of MCT8 did not increase the rate of T3-induced cell disappearance. The explanation for this discrepancy between LAT1 and MCT8 is not clear but may be related to different transport rates across the cell membrane. TH uptake by MCT8 may quickly reach equilibrium because significant TH efflux out of cells occurs (Visser et al., 2007), but efflux by LAT1 is limited potentially enabling LAT1-overexpressing cells to achieve a higher intracellular TH level (Meier et al., 2002). Further testing to establish such a mechanism is required.

Overexpression of CRYM and PKM2 increased tail muscle cell disappearance in a T3-dependent manner, which is consistent with facilitating shuttling T3 from the cytoplasm to the nucleus for TR binding. This is in contrast with previous in vitro studies showing CRYM- and PKM2-dependent decreased transcription from T3 response genes (Ashizawa et al., 1991; Mori et al., 2002). The in vivo mechanisms of these multifunction proteins need further work and may be explored with mutants, such as the PKM2KE mutant, which retains kinase activity but cannot bind T3 (Christofk et al., 2008).

For MCT8 + CRYM, we observed a huge effect, where MCT8 + CRYM increased the amount of cell disappearance to a great extent even in the $0 \mathrm{nM} \mathrm{T3}$ treatment. Our statistical analysis showed a lack of a significant T3 effect because of the high variation. Also, the interaction we observed (namely, the difference in cell disappearance between MCT 8 + CRYM and control was $88 \%$ to $57 \%$ (31\%) in the absence of T3 compared to $65 \%$ to $18 \%(47 \%)$ in the presence of T3) was not statistically significant due to high variation in the experiment. Nevertheless, our MCT8 + CRYM results are congruent with previous cell culture studies, where co-transfection of MCT8 plus CRYM had a greater transcriptional effect than either CRYM or MCT8 alone (Van Mullem et al., 2011). We hypothesize that MCT8 + CRYM is very effective at sensitizing cells to T3, such that the low level of endogenous T3 was sufficient to induce cell disappearance in tail muscle cells overexpressing MCT8 + CRYM in our assay. 


\section{Conclusions}

We used expression profiles, expression levels, and functional assays to assess the possible role of six THTs and CTHBPs in regulating the timing of TH-induced developmental change. Our expression analysis showed that in no case was a THT or a CTHBP or even TR $\beta$ itself always correlated with the timing of metamorphic change across all tissues but did suggest a role in TH-dependent development of some of these TH signaling proteins for some tissues. In accord with its extremely high sensitivity to $\mathrm{TH}$, the hind limb had the largest number of mRNAs measured favoring TH sensitivity that were highly expressed at the time of TH-dependent development, namely LAT1, MCT8, CRYM, OATP1c1 from our study as well as TR $\alpha$ and deiodinase type 2 from previous studies (Cai and Brown, 2004; Wang and Brown, 1993). Similarly, the brain is very sensitive to TH as judged by neuron proliferation early in metamorphosis and expresses high levels of LAT1, OATP1c1, PKM2, MCT8, and CRYM mRNA. The least sensitive organ, the tail, expresses lower levels of THTs and CTHBPs among tissues, and the expression of MCT8 and CRYM dramatically increases at the time of tail resorption at the end of metamorphosis. The other organs, which transform in between the extremes of hind limb and tail, had fewer THT or CTHBP expression patterns that correlated with the timing of their transformation. As with expression profiles, expression level differences among tissues for a THT or CTHBP may suggest that tissues may vary in the significance a particular TH signaling protein has for TH sensitivity. The brain had high levels of LAT1, PKM2, CRYM, and OATP1c1 mRNA, whereas the liver and intestine had high ALDH1 mRNA levels, suggesting a role in those tissues perhaps affecting TH signaling.

Our in vivo functional assays suggested that LAT1, PKM2, CRYM, and likely CRYM + MCT8 have the potential to increase T3-dependent cell disappearance. A potential mechanism underlying this effect on cell disappearance is that these genes may increase cell sensitivity/responsivity to T3. Furthermore, based on these results from the tail, expression of these genes in other tissues would sensitize cells to T3 and accelerate transformation in those tissues. On the other hand, the known dual functions of LAT1, PKM2, and CRYM leave open the possibility that such augmented cell disappearance may not solely be due to increasing TH bioavailability in the cell nucleus. In conclusion, each tissue examined appears to have a unique deployment of TH-signaling proteins, some of which we have shown to affect THdependent development in vivo, potentially underlying tissue-specific developmental timing during metamorphosis.

\section{Acknowledgments}

Support for this project was from the University of Cincinnati WISE Program to A.N. and NIH RO3 5F32DK010069-03 to D.R.B.

\section{Appendix A. Supplementary data}




\section{References}

Ashizawa and Cheng, 1992

K. Ashizawa, S.Y. Cheng

Regulation of thyroid hormone receptor-mediated transcription by a cytosol protein

Proc. Natl. Acad. Sci. U. S. A., 89 (1992), pp. 9277-9281

Ashizawa et al., 1991

K. Ashizawa, P. McPhie, K.H. Lin, S.Y. Cheng

An in vitro novel mechanism of regulating the activity of pyruvate kinase $M 2$ by thyroid hormone and fructose 1,6-

bisphosphate

Biochemistry, 30 (1991), pp. 7105-7111, 10.1021/bi00243a010

Atkinson et al., 1996

B.G. Atkinson, C. Helbing, Y. Chen

Reprogramming of genes expressed in amphibian liver during metamorphosis

Metamorphosis: Postembryonic Reprogramming of Gene Expression in Amphibian and Insect Cells, Academic Press, New York (1996)

Bates et al., 2012

Bates, D., Maechler, M., Bolker, B., 2012. lme4: Linear Mixed-effects Models using S4 Classes [version 0.999999-0]. Brown et al., 2005

D.D. Brown, L. Cai, B. Das, N. Marsh-Armstrong, A.M. Schreiber, R. Juste

Thyroid hormone controls multiple independent programs required for limb development in Xenopus laevis metamorphosis Proc. Natl. Acad. Sci. U. S. A., 102 (2005), pp. 12455-12458, 10.1073/pnas.0505989102

Buchholz et al., 2011

D.R. Buchholz, S.S. Kulkarni, A.R. Hollar, A. Ng

Hormonal Regulation and the Evolution of Frog Metamorphic Diversity in Mechanisms of Life History Evolution

Oxford University Press (2011)

Buchholz et al., 2006

D.R. Buchholz, B.D. Paul, L. Fu, Y.B. Shi

Molecular and developmental analyses of thyroid hormone receptor function in Xenopus laevis, the African clawed frog

Gen. Comp. Endocrinol., 145 (2006), pp. 1-19, 10.1016/j.ygcen.2005.07.009

Buchholz et al., 2004

D.R. Buchholz, A. Tomita, L. Fu, B.D. Paul, Y.-B. Shi

Transgenic analysis reveals that thyroid hormone receptor is sufficient to mediate the thyroid hormone signal in frog metamorphosis

Mol. Cell. Biol., 24 (2004), pp. 9026-9037, 10.1128/MCB.24.20.9026-9037.2004

Cai and Brown, 2004

L. Cai, D.D. Brown

Expression of type II iodothyronine deiodinase marks the time that a tissue responds to thyroid hormone-induced metamorphosis in Xenopus laevis

Dev. Biol., 266 (2004), pp. 87-95, 10.1016/j.ydbio.2003.10.005

Choi et al., 2015

J. Choi, K.-I.T. Suzuki, T. Sakuma, L. Shewade, T. Yamamoto, D.R. Buchholz

Unliganded thyroid hormone receptor $\alpha$ regulates developmental timing via gene repression in Xenopus tropicalis

Endocrinology, 156 (2015), pp. 735-744, 10.1210/en.2014-1554

Christofk et al., 2008

H.R. Christofk, M.G. Vander Heiden, N. Wu, J.M. Asara, L.C. Cantley

Pyruvate kinase $\mathrm{M} 2$ is a phosphotyrosine-binding protein

Nature, 452 (2008), pp. 181-186, 10.1038/nature06667

Connors et al., 2010

K.A. Connors, J.J. Korte, G.W. Anderson, S.J. Degitz

Characterization of thyroid hormone transporter expression during tissue-specific metamorphic events in Xenopus tropicalis

Gen. Comp. Endocrinol., 168 (2010), pp. 149-159, 10.1016/j.ygcen.2010.04.015

De Luze et al., 1993

A. De Luze, L. Sachs, B. Demeneix

Thyroid hormone-dependent transcriptional regulation of exogenous genes transferred into Xenopus tadpole muscle in vivo

Proc. Natl. Acad. Sci. U. S. A., 90 (1993), pp. $7322-7326$

Dhorne-Pollet et al., 2013

S. Dhorne-Pollet, A. Thélie, N. Pollet

Validation of novel reference genes for RT-qPCR studies of gene expression in Xenopus tropicalis during embryonic and postembryonic development

Dev. Dyn., 242 (2013), pp. 709-717, 10.1002/dvdy.23972 
P. Duarte-Guterman, V.S. Langlois, B.D. Pauli, V.L. Trudeau

Expression and $\mathrm{T} 3$ regulation of thyroid hormone- and sex steroid-related genes during Silurana (Xenopus) tropicalis early development

Gen. Comp. Endocrinol., 166 (2010), pp. 428-435, 10.1016/j.ygcen.2009.12.008

Friesema et al., 2003

E.C.H. Friesema, S. Ganguly, A. Abdalla, J.E. Manning Fox, A.P. Halestrap, T.J. Visser

Identification of monocarboxylate transporter 8 as a specific thyroid hormone transporter

J. Biol. Chem., 278 (2003), pp. 40128-40135, 10.1074/jbc.M300909200

Friesema et al., 2008

E.C.H. Friesema, J. Jansen, J.-W. Jachtenberg, W.E. Visser, M.H.A. Kester, T.J. Visser

Effective cellular uptake and efflux of thyroid hormone by human monocarboxylate transporter 10

Mol. Endocrinol., 22 (2008), pp. 1357-1369, 10.1210/me.2007-0112

Furlow and Neff, 2006

J.D. Furlow, E.S. Neff

A developmental switch induced by thyroid hormone: Xenopus laevis metamorphosis

Trends Endocrinol. Metab., 17 (2006), pp. 40-47, 10.1016/j.tem.2006.01.007

Gui et al., 2013

D.Y. Gui, C.A. Lewis, M.G. Vander Heiden

Allosteric regulation of PKM2 allows cellular adaptation to different physiological states

Sci. Signal., 6 (2013), p. pe7, 10.1126/scisignal.2003925

Hallen et al., 2011

A. Hallen, A.J.L. Cooper, J.F. Jamie, P.A. Haynes, R.D. Willows

Mammalian forebrain ketimine reductase identified as $\boldsymbol{\mu}$-crystallin; potential regulation by thyroid hormones

J. Neurochem., 118 (2011), pp. 379-387, 10.1111/j.1471-4159.2011.07220.x

Helbing et al., 1992

C. Helbing, G. Gergely, B.G. Atkinson

Sequential up-regulation of thyroid hormone beta receptor, ornithine transcarbamylase, and carbamyl phosphate synthetase mRNAs in the liver of Rana catesbeiana tadpoles during spontaneous and thyroid hormone-induced metamorphosis

Dev. Genet., 13 (1992), pp. 289-301, 10.1002/dvg.1020130406

Hennemann, 2001

G. Hennemann

Plasma Membrane Transport of Thyroid Hormones and Its Role in Thyroid Hormone Metabolism and Bioavailability

Endocr. Rev., 22 (2001), pp. 451-476, 10.1210/er.22.4.451

Heuer and Visser, 2009

H. Heuer, T.J. Visser

Minireview: Pathophysiological importance of thyroid hormone transporters

Endocrinology, 150 (2009), pp. 1078-1083, 10.1210/en.2008-1518

Hollar et al., 2011

A.R. Hollar, J. Choi, A.T. Grimm, D.R. Buchholz

Higher thyroid hormone receptor expression correlates with short larval periods in spadefoot toads and increases

metamorphic rate

Gen. Comp. Endocrinol., 173 (2011), pp. 190-198, 10.1016/j.ygcen.2011.05.013

Huang et al., 1999

H. Huang, N. Marsh-Armstrong, D.D. Brown

Metamorphosis is inhibited in transgenic Xenopus laevis tadpoles that overexpress type III deiodinase

Proc. Natl. Acad. Sci. U. S. A., 96 (1999), pp. 962-967

Jansen et al., 2008

J. Jansen, E.C.H. Friesema, M.H.A. Kester, C.E. Schwartz, T.J. Visser

Genotype-phenotype relationship in patients with mutations in thyroid hormone transporter MCT8

Endocrinology, 149 (2008), pp. 2184-2190

Kerney et al., 2012

R.R. Kerney, A.L. Brittain, B.K. Hall, D.R. Buchholz

Cartilage on the move: cartilage lineage tracing during tadpole metamorphosis

Dev. Growth Differ., 54 (2012), pp. 739-752, 10.1111/dgd.12002

Kitagawa et al., 1987

S. Kitagawa, T. Obata, S. Hasumura, I. Pastan, S. Cheng

A cellular 3,3-prime,5-triiodo-l-thyronine binding protein from a human carcinoma cell line: purification and characterization

J. Biol. Chem., 262 (1987), pp. 3903-3908

Liang et al., 1997

V.C. Liang, T. Sedgwick, Y.B. Shi 
Characterization of the Xenopus homolog of an immediate early gene associated with cell activation: sequence analysis and regulation of its expression by thyroid hormone during amphibian metamorphosis

Cell Res., 7 (1997), pp. 179-193, 10.1038/cr.1997.19

Livak and Schmittgen, 2001

K.J. Livak, T.D. Schmittgen

Analysis of relative gene expression data using real-time quantitative PCR and the 22DDCT method

Methods, 25 (2001), pp. 402-408

Marschner, 2012

Marschner, I.C., 2012. glm2 : Fitting Generalized Linear Models [version 1.1.1].

Matsuda et al., 2009

H. Matsuda, B.D. Paul, C.Y. Choi, T. Hasebe, Y.B. Shi

Novel functions of protein arginine methyltransferase 1 in thyroid hormone receptor-mediated transcription and in the regulation of metamorphic rate in Xenopus laevis

Mol. Cell. Biol., 29 (2009), pp. 745-757, 10.1128/MCB.00827-08

Meier et al., 2002

C. Meier, Z. Ristic, S. Klauser, F. Verrey

Activation of system $L$ heterodimeric amino acid exchangers by intracellular substrates

EMBO J., 21 (2002), pp. 580-589

Morgan et al., 2013

H.P. Morgan, F.J. O’Reilly, M.A. Wear, J.R. O’Neill, L.A. Fothergill-Gilmore, T. Hupp, M.D. Walkinshaw

M2 pyruvate kinase provides a mechanism for nutrient sensing and regulation of cell proliferation

Proc. Natl. Acad. Sci. U. S. A., 110 (2013), pp. 5881-5886, 10.1073/pnas.1217157110

Mori et al., 2002

J. Mori, S. Suzuki, M. Kobayashi, T. Inagaki, A. Komatsu, T. Takeda, T. Miyamoto, K. Ichikawa, K. Hashizume

Nicotinamide adenine dinucleotide phosphate-dependent cytosolic $\mathrm{T} 3$ binding protein as a regulator for T3-mediated transactivation

Endocrinology, 143 (2002), pp. 1538-1544

Nakajima et al., 2012

K. Nakajima, K. Fujimoto, Y. Yaoita

Regulation of thyroid hormone sensitivity by differential expression of the thyroid hormone receptor during Xenopus metamorphosis

Genes Cells, 17 (2012), pp. 645-659, 10.1111/j.1365-2443.2012.01614.x

Nakajima and Yaoita, 2003

K. Nakajima, Y. Yaoita

Dual mechanisms governing muscle cell death in tadpole tail during amphibian metamorphosis

Dev. Dyn., 227 (2003), pp. 246-255, 10.1002/dvdy.10300

Nieuwkoop and Faber, 1994

P.D. Nieuwkoop, J. Faber

Normal Table of Xenopus laevis (Daudin)

Garland Publishing Inc (1994)

Oshima et al., 2006

A. Oshima, S. Suzuki, Y. Takumi, K. Hashizume, S. Abe, S. Usami

CRYM mutations cause deafness through thyroid hormone binding properties in the fibrocytes of the cochlea

J. Med. Genet., 43 (2006), p. e25, 10.1136/jmg.2005.034397

Paul et al., 2007

B.D. Paul, D.R. Buchholz, L. Fu, Y.-B. Shi

SRC-p300 coactivator complex is required for thyroid hormone-induced amphibian metamorphosis

J. Biol. Chem., 282 (2007), pp. 7472-7481, 10.1074/jbc.M607589200

Pizzagalli et al., 2002

F. Pizzagalli, B. Hagenbuch, B. Stieger, U. Klenk, G. Folkers, P.J. Meier

Identification of a novel human organic anion transporting polypeptide as a high affinity thyroxine transporter

Mol. Endocrinol., 16 (2002), pp. 2283-2296, 10.1210/me.2001-0309

Ritchie et al., 2003

J.W.A. Ritchie, Y.-B. Shi, Y. Hayashi, F.E. Baird, R.W. Muchekehu, G.R. Christie, P.M. Taylor

A role for thyroid hormone transporters in transcriptional regulation by thyroid hormone receptors

Mol. Endocrinol., 17 (2003), pp. 653-661, 10.1210/me.2002-0179

$\underline{\text { Sachs et al., } 2004}$

L.M. Sachs, S. Le Mevel, B.A. Demeneix

Implication of bax in Xenopus laevis tail regression at metamorphosis

Dev. Dyn., 231 (2004), pp. 671-682, 10.1002/dvdy.20166

Sato et al., 2007

Y. Sato, D.R. Buchholz, B.D. Paul, Y.B. Shi 
A role of unliganded thyroid hormone receptor in postembryonic development in Xenopus laevis

Mech. Dev., 124 (2007), pp. 476-488, 10.1016/j.mod.2007.03.006

Shi et al., 1994

Y.-B. Shi, V.C.T. Liang, C. Parkison, S.-Y. Cheng

Tissue-dependent developmental expression of a cytosolic thyroid hormone protein gene in Xenopus: its role in the regulation of amphibian metamorphosis

FEBS Lett., 355 (1994), pp. 61-64, 10.1016/0014-5793(94)01173-7

Shi et al., 2002

Y.-B. Shi, J.W.A. Ritchie, P.M. Taylor

Complex regulation of thyroid hormone action: multiple opportunities for pharmacological intervention

$\underline{\text { Shi, } 1999}$

Pharmacol. Ther., 94 (2002), pp. 235-251, 10.1016/S0163-7258(02)00219-X

Y.B. Shi

Amphibian Metamorphosis: From Morphology to Molecular Biology

John Wiley \& Sons Inc (1999)

Shi et al., 1996

Y.B. Shi, J. Wong, M. Puzianowska-Kuznicka, M. Stolow

Tadpole competence and tissue-specific temporal regulation of amphibian metamorphosis: roles of thyroid hormone and its receptors

Bioessays, 18 (1996), pp. 391-399

Sindelka et al., 2006

R. Sindelka, Z. Ferjentsik, J. Jonák

Developmental expression profiles of Xenopus laevis reference genes

Dev. Dyn., 235 (2006), pp. 754-758, 10.1002/dvdy.20665

Suzuki et al., 2007

S. Suzuki, J.-I. Mori, K. Hashizume

Mu-crystallin, a NADPH-dependent T(3)-binding protein in cytosol

Trends Endocrinol. Metab., 18 (2007), pp. 286-289, 10.1016/j.tem.2007.07.002

Tata, 1958

J.R. Tata

A cellular thyroxine-binding protein fraction

Tata, 2000

Biochim. Biophys. Acta, 28 (1958), pp. 91-94

J.R. Tata

Autoinduction of nuclear hormone receptors during metamorphosis and its significance

Insect Biochem. Mol. Biol., 30 (2000), pp. 645-651, 10.1016/S0965-1748(00)00035-7

The R Core Team, 2013

The R Core Team, 2013. R: A Language and Environment for Statistical Computing [version 2.15.3].

Van Mullem et al., 2011

A.A.A. Van Mullem, R.P. Peeters, T.J. Visser

The effect of MCT8 on the biological activity of T3

Endocr. Abstr., 26 (OC5) (2011), p. 5

Visser et al., 2007

W.E. Visser, E.C.H. Friesema, J. Jansen, T.J. Visser

Thyroid hormone transport by monocarboxylate transporters

Best Pract. Res. Clin. Endocrinol. Metab., 21 (2007), pp. 223-236, 10.1016/j.beem.2007.03.008

Wang et al., 2008

X. Wang, H. Matsuda, Y.B. Shi

Developmental regulation and function of thyroid hormone receptors and 9-cis retinoic acid receptors during Xenopus

tropicalis metamorphosis

Endocrinology, 149 (2008), pp. 5610-5618, 10.1210/en.2008-0751

Wang and Brown, 1993

Z. Wang, D.D. Brown

Thyroid hormone-induced gene expression program for amphibian tail resorption

J. Biol. Chem., 268 (1993), pp. 16270-16278

Warton and Hui, 2011

D.I. Warton, F.K.C. Hui

The arcsine is asinine: the analysis of proportions in ecology

Ecology, 92 (2011), pp. 3-10

Williams et al., 2006

R. Williams, T. Holyoak, G. McDonald, C. Gui, A.W. Fenton 
Differentiating a ligand's chemical requirements for allosteric interactions from those for protein binding. Phenylalanine inhibition of pyruvate kinase

Biochemistry, 45 (2006), pp. 5421-5429, 10.1021/bi0524262

Yamauchi and Nakajima, 2002

K. Yamauchi, J. Nakajima

Effect of coenzymes and thyroid hormones on the dual activities of Xenopus cytosolic thyroid-hormone-binding protein (xCTBP) with aldehyde dehydrogenase activity

Eur. J. Biochem., 269 (2002), pp. 2257-2264, 10.1046/j.1432-1033.2002.02891.x

Yamauchi and Tata, 1994

K. Yamauchi, J.R. Tata

Purification and characterization of a cytosolic thyroid-hormone-binding protein (CTBP) in Xenopus liver

Eur. J. Biochem., 225 (1994), pp. 1105-1112, 10.1111/j.1432-1033.1994.1105b.x

Yamauchi and Tata, 1997

K. Yamauchi, J.R. Tata

Tissue-dependent and developmentally regulated cytosolic thyroid-hormone-binding proteins (CTBPs) in Xenopus

Comp. Biochem. Physiol. C Pharmacol. Toxicol. Endocrinol., 118 (1997), pp. 27-32

Yamauchi and Tata, 2001

K. Yamauchi, J.R. Tata

Characterization of Xenopus cytosolic thyroid-hormone-binding protein (xCTBP) with aldehyde dehydrogenase activity

Chem. Biol. Interact., 130-132 (2001), pp. 309-321, 10.1016/S0009-2797(00)00274-X

Yoshizato and Frieden, 1975

K. Yoshizato, E. Frieden

Increase in binding capacity for triiodothyronine in tadpole tail nuclei during metamorphosis

Nature, 254 (1975), pp. 705-707 